\title{
Morphological, enzymatic screening, and phylogenetic analysis of thermophilic bacilli isolated from five hot springs of Myagdi, Nepal
}

\author{
Punam Yadav ${ }^{1,2}$, Suresh Korpole ${ }^{3}$, Gandham S Prasad ${ }^{3}$, Girish Sahni ${ }^{3}$, Jyoti Maharjan ${ }^{1}$, Lakshmaiah Sreerama ${ }^{4}$, \\ Tribikram Bhattarai ${ }^{2}$ \\ ${ }^{1}$ Molecular Biotechnology Unit, Nepal Academy of Science and Technology, Khumaltar, Lalitpur, Nepal, ${ }^{2}$ Central Department of Biotechnology, Tribhuvan \\ University, Kirtipur, Nepal, ${ }^{3}$ Microbial Type Culture Collections, Institute of Microbial Technology, Chandigarh, India, ${ }^{4}$ Department of Chemistry and Earth \\ Sciences, Qatar University, Doha, Qatar
}

\section{ARTICLE INFO \\ Article history: \\ Received on: September 13, 2017 \\ Accepted on: November 23, 2017 \\ Available online: April 05, 2018}

Key words:

Thermostable enzymes,

Amylase,

Cellulase,

Xylanase,

Hot springs,

Biochemical,

Anoxybacillus

\section{ABSTRACT}

The present study was conducted to identify and characterize the thermophilic bacteria isolated from five hot springs, namely, Sinkosh, Singha, Bhurung, Ratopani, and Paudwar located in Myagdi district, Nepal, using phenotypic and genotypic methods. The hot spring has temperature $42-62^{\circ} \mathrm{C}$ and $\mathrm{pH} 6.5-6.8$. Isolation of thermophiles was done using simple enriched nutrient broth media at $60^{\circ} \mathrm{C}$. Selected strains were screened for thermostable enzymes; cellulase, hemicellulase, amylase, protease, gelatinase, and lipase using substrates carboxymethylcellulose, xylan, soluble starch, casein, gelatin, and Tween $(20,40,60$, or 80$)$, respectively. The bacteria were grouped into 16 groups based on morphological and biochemical characteristics. 16S rRNA sequence analysis of 16 isolates and phylogenetic analysis showed a cluster of five distinct taxonomic groups. The groups were identified as genus Anoxybacillus, Aeribacillus, Brevibacillus, Bacillus, and Geobacillus, based on $\geq 95 \%$ similarity with reference strains. This is the first study that reports Anoxybacillus sp., Brevibacillus sp., and Aeribacillus sp. from the hot springs of Nepal.

\section{INTRODUCTION}

Hot springs represent unique geothermal environments supporting extremophilic microorganisms that include members of all three domains of life, Archaea, Bacteria, and Eukarya [1,2]. Thermophiles can grow at higher temperatures $\left(55-80^{\circ} \mathrm{C}\right)$ as they possess physically and chemically stable enzymes showing high metabolism also at the higher temperature. Their study has become a major domain of research due to their potential to produce industrially interesting thermostable enzymes (proteases, amylases, lipases, xylanases, and DNA polymerases) and exopolysaccharides that function under extreme conditions [3]. Thermophilic organisms grow in a limited number of sites, and exploration of such microorganisms from geothermal environments has not only provided greater insights into the origin and evolution of earliest life but also has provided access to significant bioresources with potential applications in food and biotechnology industry [4]. Therefore, thermophiles are of interest to enhance the thermostability of industrial enzymes [5].

\footnotetext{
*Corresponding Author

Punam Yadav,

Nepal Academy of Science and Technology,

Kathmandu, Nepal.

Email: punamyadav.10oct@gmail.com
}

Bioethanol, the most common renewable fuel today, is commonly derived from corn grain (starch) or sugarcane (sucrose) [6]. The production of bioethanol from starch and sugarcane is often criticized as it may affect the human food chain. Such bioresources are limited to be able to use for biofuel production and compete to replace or even partially supplement fossil fuels. Renewable lignocellulosic biomass from agricultural waste, weeds, and forest biomass, relatively abundant, may be used for large-scale production of alcohol-based fuels, and the process can be cost-efficient [7]. One of the limitations of this process is the complex and crystalline structure of lignocellulose that makes it difficult to hydrolyze to fermentable sugar [8]. Use of thermostable enzymes and thermophilic microorganisms for the degradation of the lignocellulosic material offers an advantage of minimizing the risk of contamination, and it may lead to the single-step process of enzymatic hydrolysis and fermentation [9].

In Nepal, there are more than 28 hot springs stretching right across a Southeast-Northwest elongated region. The distribution of these hot springs is mainly restricted to the Main Central Thrust area of Nepal that separates the higher Himalayan zone from the lesser Himalayan zone [10]. None of these hot springs have been explored in detail for the microbial community; accordingly, their biological diversity and biotechnological potential remain to be explored. Myagdi district of Nepal is endowed with several hot springs, which could be the potential source of thermophilic bacteria. 
Nepal is one of the countries with no any conventional fuel sources and is entirely dependent on imported fuel. A recent search for biofuel in Nepal has mainly focused on the diesel plant, Jatropha other than this; molasses has been the major feedstock for ethanol production. However, molasses cannot fulfill all the needs of alternative fuel. Therefore, other possible nonfood-based alternative such as lignocellulosic wastes from agro-based industries can be a potential source of bioethanol production, and Nepal is one of the agricultural economy-based countries, also exist many industries such as paper industry and textile industry, in which the industrial waste is primarily lignocellulosic waste [11]. Thus, through these lignocellulolytic bacteria isolated from the hot spring of Nepal and their enzyme system can act as the bioremediation tools.

\section{MATERIALS AND METHODS}

\subsection{Sampling Site}

Samples were collected from five different hot springs located in Myagdi district, namely, Sinkosh, Singha, Bhurung, Ratopani, and Paudwar [Figure 1] on October 2013. The location of sampling site is described in Table 1. Water samples were collected from streams, tributaries, and overflow channels as close to the center of flow as possible. Biomats were collected with a sterile spatula, kept in zipping locked plastic bags, and brought to the laboratory of Nepal Academy of Science and Technology, Kathmandu, Nepal.

\subsection{Cultivation of Thermophilic Bacteria}

One gram of biomats was suspended in $10 \mathrm{ml}$ of sterile distilled water that served as a stock sample. $1 \mathrm{ml}$ of biomats and $1 \mathrm{ml}$ of sterile hot water samples were used for dilutions under sterile conditions. Spread plate and pour plate methods were used to obtain pure colonies. The diluted cultures $(100 \mu \mathrm{L})$ were evenly spread on nutrient agar (NA) plates and the plates were incubated at $60^{\circ} \mathrm{C}$ for $24-48 \mathrm{~h}$. Isolates were grouped based on differences in the shape, color, and size of the colony [12]. The pure cultures on NA medium were transferred to freshly prepared NA slant. Glycerol stocks were made and stored for further study.

\subsection{Morphological and Biochemical Test}

Colony morphology was determined after 2-4 days growth on NA plates incubated at $60^{\circ} \mathrm{C}$. Each isolate was examined by Gram staining and endospore staining [13]. Most of the biochemical tests were performed according to MacFaddin [14]. Each isolated colony was streaked on NA slants and incubated at $60^{\circ} \mathrm{C}$ for up to $48 \mathrm{~h}$ to obtain abundant growth. The following tests were carried for potential strains: Oxidase, catalase, methyl red; Voges-Proskauer, and indole production. The temperature and $\mathrm{pH}$ range were determined by incubating the bacteria at different temperatures and $\mathrm{pH}$, respectively.

\subsection{Screening for Industrially Important Enzymes}

The isolated pure cultures were used for screening of industrially important enzymes: Amylase, lipase, protease, cellulase, hemicellulase, and gelatinase. All screenings were done in bacterial cultures grown for $24-48 \mathrm{~h}$ at $60^{\circ} \mathrm{C}$. Plates were also further incubated for slowgrowing thermophiles.

\subsubsection{Amylase}

Screening of the amylase activity was performed on starch agar medium (Himedia, Bengaluru, India). The presence of amylase activity was confirmed by the appearance of a clear halo zone around the colonies after staining with Gram's iodine solution [15].

\subsubsection{Protease}

Screening of protease activity was performed on skimmed milk agar medium (Himedia, Bangalore, India) containing 0.5\% tryptone, $0.3 \%$ yeast extract, $1.5 \%$ agar, and $25 \%$ skimmed milk. Protease activity was confirmed by the appearance of a clear zone around the colonies indicating degradation of milk casein [16].

\subsubsection{Cellulase}

Determination of the cellulase activity was performed on NA (Himedia, Bangalore, India) containing 0.2\% carboxymethylcellulose (CMC). Cellulase activity was identified by the appearance of a clear halo around the tested strain after treatment with Gram's iodine [17].

\subsubsection{Xylanase}

Testing of xylanase activity was done on NA (Himedia, Bangalore, India) medium containing $0.5 \%$ beechwood xylan (Sigma Chemical Co., St Louis, USA). The presence of xylanase activity was confirmed by the appearance of a clear zone around the strain tested following the staining with Gram's iodine [18].

\subsubsection{Lipolytic enzymes}

For lipolytic activity nutrient, agar medium (Himedia, Bangalore, India) was supplemented with $1 \%$ of Tween 20 , Tween 40 , Tween 60 , or Tween 80 . An opaque halo around the colonies indicated the positive lipolytic activity [19].

\subsubsection{Gelatinase}

Screening of gelatinase activity was performed on gelatinase agar (Himedia, Bangalore, India) containing (g/l) gelatin 30.0, casein enzymatic hydrolysate 10.0 , sodium chloride 10.0, agar 15.0, and final $\mathrm{pH}$ (at $25^{\circ} \mathrm{C}$ ) $7.0 \pm 0.2$. The appearance of a clear zone around the colony indicated gelatinase positive [20].

\subsection{Production of Enzymes and Assessment of their Activity}

Strains showing comparatively larger halo zone were selected for further assay of amylase, cellulase, and xylanase production.

\subsubsection{Cellulase production}

Cellulase activity in the strains was determined in cultures grown in minimal salt solution (MSS). MSS contained (g/l) $\mathrm{NaNO}_{3} 0.5$, $\mathrm{K}_{2} \mathrm{HPO}_{4} 1.0, \mathrm{MgSO}_{4} .7 \mathrm{H}_{2} \mathrm{O} 0.5, \mathrm{FeSO}_{4} .7 \mathrm{H}_{2} \mathrm{O} 0.01$, and yeast extract 1.0 containing $0.5 \% \mathrm{CMC}$ at $\mathrm{pH} 7$. Cultures were incubated for $24 \mathrm{~h}$ at $60^{\circ} \mathrm{C}$ and $180 \mathrm{rpm}$ [21]. Culture was centrifuged at $\times 12000 \mathrm{~g}$ for $20 \mathrm{~min}$ at $4^{\circ} \mathrm{C}$. Enzyme extract, $500 \mu$, was added to $500 \mu 1$ of $1 \% \mathrm{CMC}$ solution prepared in $0.1 \mathrm{M}$ sodium phosphate buffer $\mathrm{pH}$ 7. The mixture was incubated for $30 \mathrm{~min}$ at $60^{\circ} \mathrm{C}$ and $180 \mathrm{rpm}$. Then, $2 \mathrm{ml}$ of 3,5-dinitrosalicylic acid (DNSA) reagent was added, boiled for $10 \mathrm{~min}$, and cooled in water to stabilize the color formation. The absorbance was measured at $540 \mathrm{~nm} .1$ unit of activity was defined as the amount of enzyme required to produce $1 \mu$ mole of reducing sugar per minute $[22,23]$.

Table 1: Location (coordinates) and physical characters of five hot springs of Myagdi district, Nepal

\begin{tabular}{lllccc} 
Hot & \multicolumn{2}{l}{ GPS location } & Elevation & pH & Temperature \\
\cline { 2 - 3 } Springs & Northing & Easting & & & \\
Sinkosh & $28^{0} 34.801^{\prime}$ & $083^{0} 23.517^{\prime}$ & $1903 \mathrm{M}$ & 6.6 & 42.3 \\
Singha & $28^{0} 22.067^{\prime}$ & $083^{0} 30.149^{\prime}$ & $898 \mathrm{M}$ & 6.9 & 50.2 \\
Ratopani & $28^{0} 28.702^{\prime}$ & $083^{0} 38.473^{\prime}$ & $1170 \mathrm{M}$ & 7.2 & 57.4 \\
Bhurung & $28^{0} 29.742^{\prime}$ & $083^{0} 39.242^{\prime}$ & $1183 \mathrm{M}$ & 6.7 & 60.7 \\
Paudwar & $28^{0} 30.013^{\prime}$ & $083^{0} 39.340^{\prime}$ & $1235 \mathrm{M}$ & 6.8 & 65.3 \\
\hline
\end{tabular}




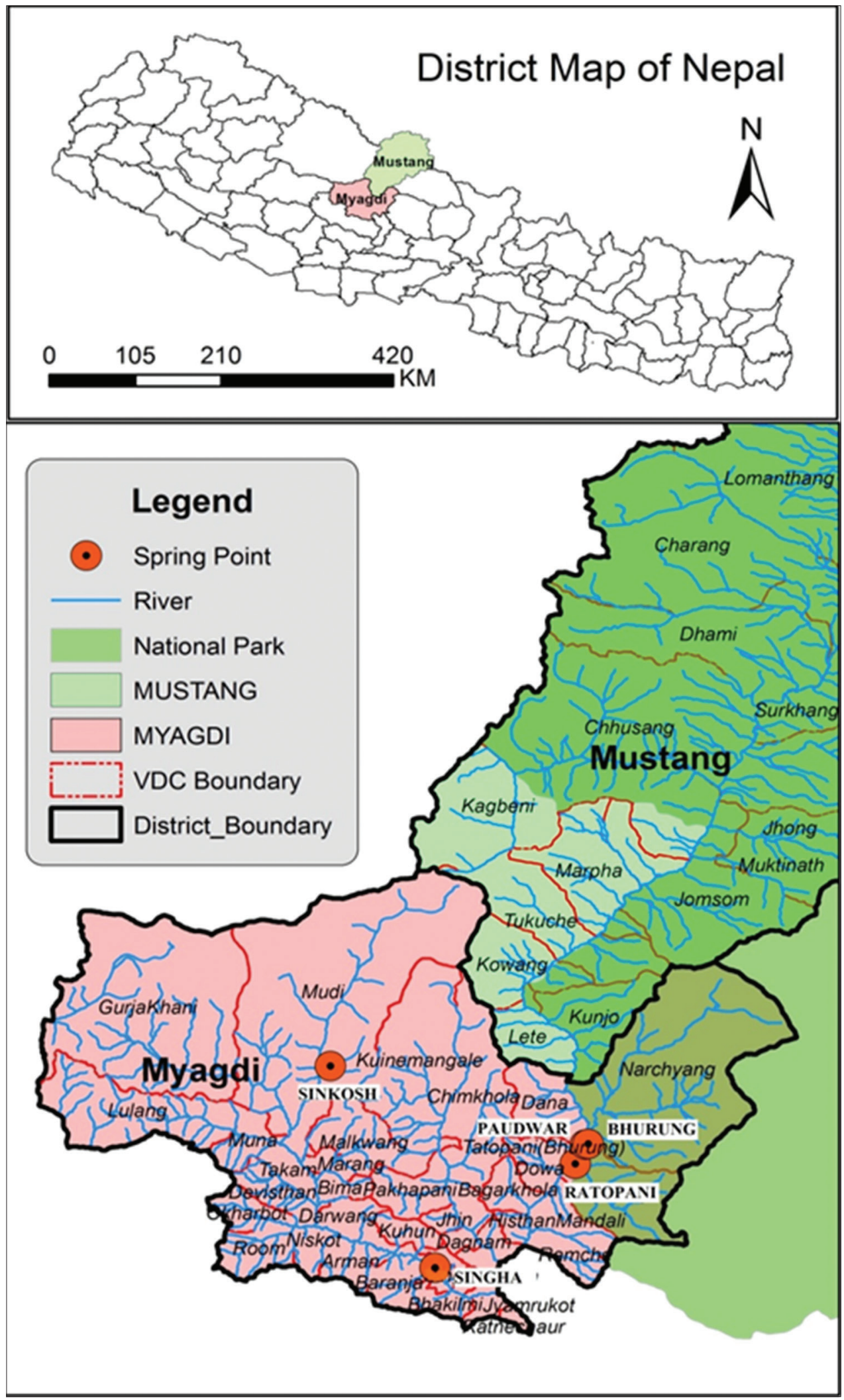

Figure 1: Site of sample collection located in Myagdi district, Nepal (Courtesy: Survey of Nepal)

\subsubsection{Xylanase production}

Xylanase activity was determined by testing the strains cultured in MSS described above containing $0.5 \%$ beechwood xylan at $\mathrm{pH}$ 7. Cell-free supernatant was used as xylanase enzyme source and the xylanase activity was determined by DNSA method described as above. 1 unit of xylanase activity was defined as the amount of enzyme required to produce $1 \mu \mathrm{mol}$ of xylose per minute [24]. 


\subsubsection{Amylase production}

Starch degrading isolates were subcultured in MSS containing $0.5 \%$ starch. Cell-free supernatant was estimated for amylase activity by DNSA method as mentioned above. 1 unit of amylase activity was defined as the amount of enzyme that reduces the absorbance of the iodine-starch complex at $620 \mathrm{~nm}$ by $1 \% / \mathrm{min}$ [25].

\subsubsection{Extracellular, cell-bound, and intracellular cellulase activity}

Isolated microbial strains were grown in MSS medium supplemented with $1 \% \mathrm{CMC}$ at $60^{\circ} \mathrm{C}$. Culture broth was centrifuged at $\times 12000 \mathrm{~g}$ for $20 \mathrm{~min}$, and the supernatant was used as extracellular cellulose enzyme source. The pellets were resuspended in $1 \mathrm{M}$ sodium phosphate buffer at $\mathrm{pH} 7$ and sonicated (Sonics-Vibracell ultrasonic processor, Newton, CT, USA) keeping Sonifier output at 70 amp (20 strokes of the $30 \mathrm{~s}$ each with $10 \mathrm{~s}$ interval each at $4^{\circ} \mathrm{C}$ ). The cell homogenates were centrifuged at $\times 12000 \mathrm{~g}$ for $20 \mathrm{~min}$ and the supernatant was used as the intracellular enzyme. The pellet after centrifugation was suspended in buffer and used for the measurement of cell-bound enzyme activity [26].

\subsection{DNA Extraction and 16S rRNA Gene Amplification}

Chromosomal DNA was extracted using the DNA Purification Kit (Promega Inc., Madison, WI, USA). 16S rRNA gene was amplified using universal primers $27 \mathrm{f}$ (5'-AGAGTTTGATCCTGGCTCAG-3') and 1492r (5'-GGTTACCTTGTTACGACTT-3') [27]. The amplified product was purified, using a QIA quick PCR purification kit (Qiagen Inc., San Diego, CA, USA), and sequenced in an ABI Prism 3700 automatic DNA sequencer by the use of a BigDye Terminator Cycle Sequencing kit (Applied Biosystems, Inc., Palo Alto, CA, USA) [28].

\subsection{Phylogenetic Analysis}

The sequence of the 16S rRNA gene obtained was used for the initial BLAST search. The BLAST analysis was performed through the EZTaxon server [29]. Sequences closely related were retrieved manually from National Center for Biotechnology Information database (http://www. ncbi.nlm.nih.gov), and the sequences were aligned using the ClustalW program, and the results obtained were edited manually. Phylogenetic trees were reconstructed using the neighbor-joining (NJ) and maximumlikelihood (ML) methods available in the MEGA6 software. Evolutionary distances between the NJ and ML trees were calculated using Kimura's two parameters and Tamura-Nei models, respectively [30].

\section{RESULTS}

\subsection{Phenotypic Characteristics of Selected Strains}

A total of 150 thermophilic (growing above $60^{\circ} \mathrm{C}$ ) bacteria were isolated. All isolates were Gram-positive, rod-shaped, and endosporeforming. The strains showed different types of colonies (large, matt, or granular) with variable shapes (circular, regular edges, or jagged) or colonies with wavy contours and creamy consistency. Optimum growth was between $55^{\circ} \mathrm{C}$ and $65^{\circ} \mathrm{C}$, while the growth was drastically reduced at a temperature above $70^{\circ} \mathrm{C}$. Only eight isolates tolerate $75^{\circ} \mathrm{C}$ and none was able to grow at $80^{\circ} \mathrm{C}$.

\subsection{Isolates Producing Industrially Important Enzymes}

All 150 isolates were screened for hydrolase activity. Out of 150 isolates, 135 isolates produced at least one extracellular hydrolytic enzyme, 100 produced amylases, 95 produced cellulase, 85 produced xylanase, and 15 produced lipases. Only one strain produces gelatinase and proteases. Based on morphological, biochemical, and enzymatic screening [Table 2], the isolates were divided into 16 groups.

\subsection{S rRNA Gene Sequence and Phylogenetic Analysis}

One isolate from each group was taken for further molecular characterization from 16S RNA gene sequence. DNA fragments with a size of about $1.5 \mathrm{kbs}$ of 16 isolates were amplified. BLAST analysis of 16S rRNA gene showed high homology with Bacillus, Brevibacillus, Geobacillus, Aeribacillus, and Anoxybacillus genera. The closest relationship of each sequence was determined by constructing phylogenetic trees.

Table 2: Bacterial isolates grouped based on their temperature tolerance and hydrolase activity

\begin{tabular}{|c|c|c|c|c|}
\hline Groups & Isolates & Temperature $\left({ }^{\circ} \mathrm{C}\right)$ & Hydrolytic enzyme activity & Isolates identification* \\
\hline I. & NAST PD13 & $30-70$ & C+; X+; A+; G-; P-; G-; T20-; T40-; T60-; 80- & Anoxybacillus kamchatkensis \\
\hline II. & NAST PD17 & $42-75$ & C+; X+; A+; G-; P-; G-; T20-; T40-; T60-; 80- & Anoxybacillus salavatliensis \\
\hline III. & NAST RP5 & $50-75$ & C-; X-; A(+); G-; P-; G-; T20-; T40-; T60-; 80- & Geobacillus toebii \\
\hline IV. & NAST SK 28 & $42-75$ & C-; X-; A-, G-; P-; G-; T20-; T40-; T60-; 80- & Aeribacillus pallidus \\
\hline $\mathrm{V}$. & NAST PD15 & $55-75$ & $\mathrm{C}(+) ; \mathrm{X}(+) ; \mathrm{A}(+) ; \mathrm{G}+; \mathrm{P}-; \mathrm{G}-;$ T20-; T40-; T60-; 80- & Aeribacillus pallidus \\
\hline VI. & NAST RP11 & $42-75$ & C-; X-; A-, G+; P-; G+; T-20-; T40-; T60-; 80- & Aeribacillus pallidus \\
\hline VIII. & NAST PD16 & $42-75$ & C-; X-; A+; P-; G-; T-20-; T40-; T60-; 80- & Geobacillus toebii \\
\hline IX. & NAST SG19 & $30-70$ & C+; X-; A+; P-, G-, T-20-; T40-; T60-; 80- & Anoxybacillus salavatliensis \\
\hline $\mathrm{X}$. & NAST SG29 & $30-75$ & $\mathrm{C}+; \mathrm{X}(+) ; \mathrm{A}+; \mathrm{P}-; \mathrm{G}-; \mathrm{T}-20-;$ T40-; T60-; 80- & Anoxybacillus kamchatkensis \\
\hline XI. & NAST SG22 & $30-75$ & C+; X-; A+; P-, G-, T-20-; T40+; T60-; 80- & Anoxybacillus flavithermus \\
\hline XII. & NAST BR26 & $42-75$ & $\mathrm{C}+; \mathrm{X}+; \mathrm{A}+; \mathrm{P}-; \mathrm{G}-; \mathrm{T}-20+; \mathrm{T} 40+; \mathrm{T} 60+; 80-$ & Anoxybacillus salavatliensis \\
\hline XVI. & NAST BR17 & $37-75$ & $\mathrm{C}+; \mathrm{X}+; \mathrm{A}+; \mathrm{P}+; \mathrm{G}-; \mathrm{T}-20-; \mathrm{T} 40-; \mathrm{T} 60-; 80-$ & Bacillus thuringiensis \\
\hline
\end{tabular}

*Identified based on 16S RNA sequence comparison, C: Cellulase, X: Xylanase, A: Amylase, G: Gelatinase, P: Protease, T: Tween, +: Positive, -: Negative, (+): Weakly positive 
Phylogenetic tree enables to claim that the isolates belong to five genera [Figure 2], i.e. Brevibacillus, Aeribacillus, Geobacillus, Bacillus, and Anoxybacillus. Analysis of microbial communities of Myagdi hot springs showed the presence of eight different species of Bacilli: Anoxybacillus kamchatkensis, Anoxybacillus salavatliensis, Anoxybacillus flavithermus, Aeribacillus pallidus, Geobacillus toebii, Geobacillus galactosidasius, Brevibacillus thermoruber, and Bacillus thuringiensis. Anoxybacillus dominated in all five hot springs.

The detailed phylogenetic analysis of the bacterial community is first time reported from the five hot springs located in Myagdi, Nepal. Bacillus licheniformis, Bacillus subtilis, and Bacillus pumilus had been reported earlier from Bhurung hot spring [31], but these bacteria were not found in the present study. Anoxybacillus sp., Brevibacillus sp., and Aeribacillus sp. isolated in this study are reported first time from Nepal.

\subsection{Biochemical Characterization}

Four isolates such as NAST SG1, NAST PD13, NAST BR26, and NAST SK12 were selected on the basis of their thermostability, and cellulase and xylanase activity for further biochemical analysis. The detail biochemical characters are given in Table 3. Fundamental reasons to choose thermostable enzymes are due to their unique characteristics of long shelf life, increased tolerance to organic solvents, reduced risk of microbial contamination, minimal loss of enzyme activity during processing at the elevated temperatures, and their possible benefit in pre-treatment of biomass [32]. Results show that NAST PD13, NAST BR26, NAST SK12, and NAST SG1 belonging to genus Anoxybacillus show variation in their biochemical characteristics such

Table 3: Phenotypic characteristics of the isolates selected by their potential as enzyme producers

\begin{tabular}{lcccc} 
Biochemical & NAST & NAST & NAST & NAST SG1 \\
characters & PD13 & BR26 & SK12 & \\
Catalase & + & + & + & + \\
Oxidase & + & + & + & + \\
Methyl red & + & + & + & + \\
Voges-Proskauer & - & + & + & + \\
Indole test & - & - & - & - \\
Hydrolysis of & & & & \\
Gelatin & - & - & - & - \\
Casein & - & - & - & - \\
Starch & + & + & + & + \\
Cellulose & + & + & + & + \\
Xylan & + & + & + & + \\
Tween 20 & - & + & + & - \\
Tween 40 & - & + & + & - \\
Tween 60 & - & + & - & - \\
Tween 80 & - & + & - & - \\
Esculin & + & - & - & - \\
Growth at $27^{\circ} \mathrm{C}$ & - & - & - & - \\
Growth at $37^{\circ} \mathrm{C}$ & - & - & - & - \\
Growth at $42-75^{\circ} \mathrm{C}$ & + & + & + & + \\
Optimum & $60^{\circ} \mathrm{C}$ & $60^{\circ} \mathrm{C}$ & $60^{\circ} \mathrm{C}$ & $60^{\circ} \mathrm{C}$ \\
temperature & & & & \\
Optimum pH & 7 & 7 & 6.5 & - \\
\hline & & & & + \\
\hline & & & & + \\
\hline
\end{tabular}

as growth temperature, $\mathrm{pH}$, hydrolysis of Tween, and Esculin. Further detail study can reveal some novel characteristics too.

\subsection{Production of Enzymes and Assessment of their Activity}

Quantitative analysis of extracellular amylase, cellulase, and xylanase production from NAST SG1, NAST PD13, NAST BR26, and NAST SK12 showed higher extracellular xylanase and amylase production compared to cellulase [Figure 3]. Among four isolates, NAST PD13 showed highest cellulase $(0.31 \mathrm{IU} / \mathrm{ml})$, xylanase $(3.02 \mathrm{IU} / \mathrm{ml})$, and amylase $(5.15 \mathrm{IU} / \mathrm{ml})$ activity. Among Anoxybacillus sp., only $A$. flavithermus, and Anoxybacillus sp., 527 are reported as cellulose degrader [33]. However, in the present result, A. salvatliensis (NAST BR26) and A. kamchatkensis (NAST PD13) also degraded cellulose. Multiple enzyme systems aid in creating an efficient degradation of the lignocellulosic materials composed of cellulose, hemicellulose, pectin, and lignin.

\subsection{Extracellular, Cell-bound, and Intracellular Cellulase Activity}

For microorganisms to hydrolyze and metabolize insoluble cellulose, extracellular cellulase must be produced that are either free or cell associated [34,35]. It was noticed that all four strains, namely, NAST-SG1, NAST-SK12, NAST-PD13, and NAST-BR26, produce all three types of cellulase (exoglucanases), i.e., they are present in extracellular, intracellular as well as cell-bound fractions. Result shows

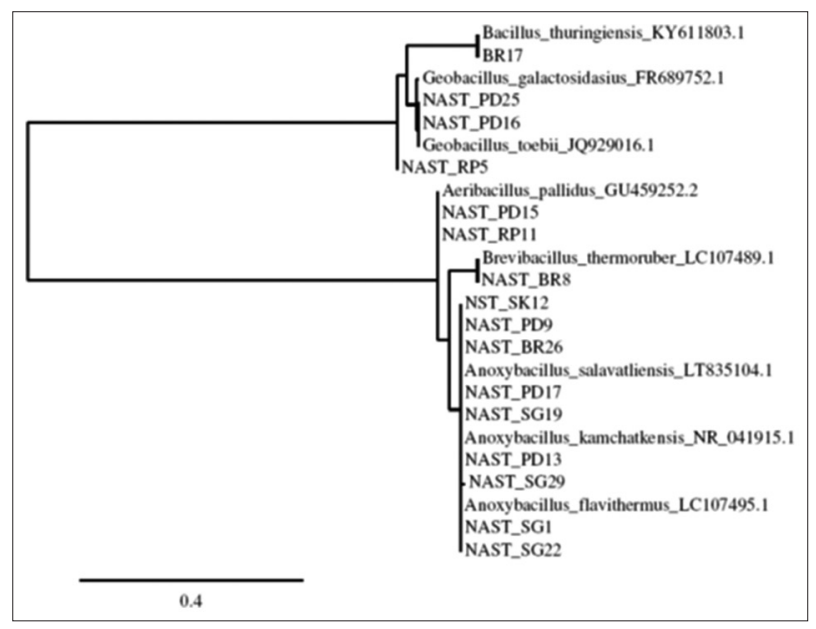

Figure 2: Phylogenetic tree based on 16S DNA sequences of thermophilic bacteria isolated from five hot springs of Myagdi, Nepal.

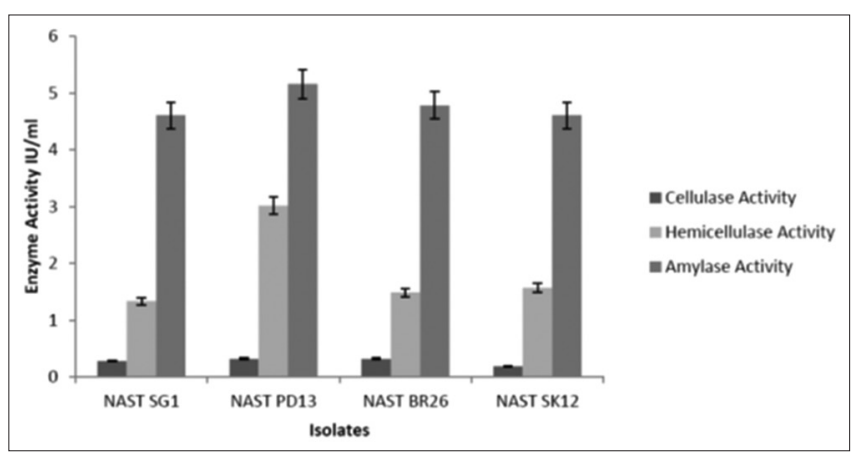

Figure 3: Cellulase, xylanase, and amylase activity of the four bacterial isolates such as NAST SG1, NAST PD13, NAST BR26, and NAST SK12. 
endoglucanase concentrations are highest in cell-bound fractions [Figure 4] of NAST-SG1 (1.42 IU/mL), NAST-SK12 (0.91 IU/mL), NAST-PD13 (0.84 IU/mL), and NAST-BR26 (0.86 IU/mL).

\section{DISCUSSION}

Samples collected from five different hot springs were analyzed in NB medium as NA medium. NA is suitable for growing the Bacilli groups and the Bacillus species are of increasing importance in industry and medicine and that diagnosis to the species level is highly desirable in many instances [36]. The use of other enrichment media may likely to recover different and some novel microbes [37].

All the isolated strains were able to grow at $30-70^{\circ} \mathrm{C}$, with optimal growth temperature at $60^{\circ} \mathrm{C}$. Thus, all strains could be classified as thermophiles $[38,39]$. The temperature of hot springs was below $60^{\circ} \mathrm{C}$ except at Bhurung and Paudwar hot springs which show that any microbes do not necessarily have the same optimum temperature as their natural habitats [40].

Cultivated microbial community within the five hot springs of Myagdi belongs to genus Brevibacillus, Aeribacillus, Geobacillus, Bacillus, and Anoxybacillus and had a close relationship to $A$. kamchatkensis, A. salvatliensis, A. flavithermus, A. pallidus, G. toebii, G. galactosidasius, B. thermoruber, and B. thuringiensis predominated by Anoxybacillus in all five hot springs. All the isolated microbes belong to the domain Bacteria, phylum Firmicutes, class Bacilli, and order Bacillales (http://rdp.cme.msu.edu/set match). As NA medium is suitable for growing the bacilli group [33], therefore, there was great probability of isolating mostly thermophilic bacilli from the hot springs. The use of other enrichment media may likely to recover different and some novel microbes [37].

Genera, Geobacillus, Anoxybacillus, Brevibacillus, and Bacillus, are commonly reported in thermal environments including hot springs, oil reservoirs, mines, and geothermal aquifers. The genera Bacillus and Brevibacillus have also been isolated from mesobiotic environments.

In the context of Nepal, no such detailed phylogenetic analysis of the bacterial community is yet reported from the hot spring ecosystem. Till date, B. licheniformis, B. subtilis, and B. pumilus have been reported from Bhurung hot spring of Myagdi district, Nepal [31]. This is the first study on the microbial diversity of thermophiles in five different hot springs of Myagdi district. This study reports first time Anoxybacillus sp., Brevibacillus sp., and Aeribacillus sp. from the hot springs of Nepal.

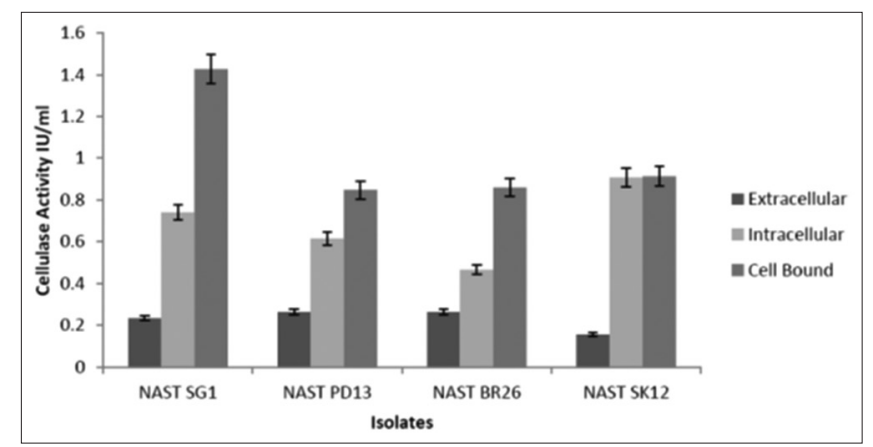

Figure 4: Extracellular, intracellular, and cell-bound endoglucanase activity of four bacterial isolates such as NAST SG1, NAST PD13, NAST BR26, and NAST SK12 grown in carboxymethyl cellulose medium.
Here, we report the microbial community analysis of Myagdi hot spring, and the analysis was based on culture-dependent strategies to get a first insight into the microbial communities in this ecosystem which may be the limitation of this study. Consequently, it has been reported that the microbial diversities analyzed by culture-independent methods show higher diversity than culture-dependent method [38]. Therefore, culture-independent methods can give more detail on the diversity of the thermophilic community of Myagdi hot springs.

Screening of thermostable enzymes cellulase, hemicellulase, lipase, amylase, gelatinase, and protease from the isolated strain showed at least one hydrolase activity. Fundamental reasons to choose thermostable enzymes is due to their certain properties such as intrinsic thermostability, which implies possibilities of long shelf life, increased tolerance to organic solvents, reduced risk of microbial contamination, as well as low activity losses during processing even at the elevated temperatures and their possible benefit in pretreatments [32]. Such enzymes will have better commercial value. In addition, several microorganisms produce multiple individual enzymes that can act synergistically and hydrolyze the polymeric lignocellulose into shorter metabolizable intermediates. Therefore a cost-efficient process of the renewable resource (agricultural and forest biomass) available in large enough quantities can be considered for large-scale production of alcohol-based fuels [41]. The lignocellulosic materials are often subjected to thermal treatments to facilitate its degradation; accordingly, the thermostable strains producing thermostable enzymes will be of great advantage to it [42]. NAST SG1, NAST PD13, NAST BR26, and NAST SK12 apparently produce thermally stable cellulase, hemicellulase, and amylase enzymes. We believe these strains can be used to improve utilization of the lignocellulosic carbohydrate biomass to produce alcohol-based biofuels.

Enzyme production experiments in previous studies show that bacterium has both extracellular and cell-bound endoglucanase activities, of which up to $80 \%$ of all cellulose enzyme fraction is found in the extracellular fluid and it is consistent with other stationary-phase cellulose-grown cultures $[35,43]$. The location of cellulase has not been identified in Anoxybacillus sp. but extracellular endoglucanase has been reported in prolonged incubation. Amylopullulanase of the thermophilic Anoxybacillus sp. SK3-4 (ApuASK) was detected in cell-bound fraction [44]. The emerging picture is that association of fibrolytic enzymes within cell differs from one enzyme to another and with the age of the cell. From studies of cell-associated cellulase in Ruminococcus albus and R. flavefaciens, cellulase appears to vary from partially to complete cell associated depending on the strain and growth condition. $R$. flavefaciens was largely cell associated during exponential growth and was found in the extracellular fluid when cell aged [45]. Use of cell-free supernatants in the early stage for enzyme assay in this study, therefore, may have underrepresented cellulase activity. In thermophiles, the problem associated with enzyme production is also due to low cell yield associated with their growth. Special equipment, process configuration, medium compositions, and culture optimizations can increase cell yield in thermophilic bacteria and may also increase cellulase production $[30,46]$.

Nepal has many geothermal areas with different physical and chemical properties. Detail study on microbial diversity will provide the opportunity to explore novel thermophilic microbes. Cultivation method is the limitation of this study because the distinctions are not based mainly on DNA relatedness studies, molecular probing, and chemotaxonomic analyses but also characteristic of phenotypic profiles and biochemical reactivity of the isolates [47]. 
Although this is not the first report of thermophilic Bacillus from hot spring of Myagdi, Nepal and could be a potential source of a thermostable enzyme of industrially important hydrolase that can have many industrial applications. Efforts are made to optimize lignocellulose-degrading enzymes production in different temperature and $\mathrm{pH}$ and to purify the enzyme.

\section{ACKNOWLEDGMENT}

Punam Yadav worked in Microbial Type Culture Collection (MTCC) Department at CSIR - Institute of Microbiology, Chandigarh, India for the analysis of bacterial isolates. Her research and stay in India were supported by TWAS-CSIR Sandwich Ph.D. Program (Grant 2014). We thank Institute of CSIR - Institute of Microbial Technology, Chandigarh, India, for all technical support.

\section{REFERENCES}

1. Averhoff B, Müller V. Exploring research frontiers in microbiology: Recent advances in halophilic and thermophilic extremophiles. Res Microbiol 2010;161:506-14.

2. Meyer-Dombard D, Shock E, Amend J. Archaeal and bacterial communities in geochemically diverse hot springs of Yellowstone National Park, USA. Geobiology 2005;3:211-27.

3. Aanniz T, Ouadghiri M, Melloul M, Swings J, Elfahime E, Ibijbijen J, et al. Thermophilic bacteria in moroccan hot springs, salt marshes and desert soils. Braz J Microbiol 2015;46:443-53.

4. Badhai J, Ghosh TS, Das SK. Taxonomic and functional characteristics of microbial communities and their correlation with physicochemical properties of four geothermal springs in Odisha, India. Front Microbiol 2015;6:1166.

5. Bisht SS, Panda AK. Biochemical characterization and 16S rRNA sequencing of few lipase-producing thermophilic bacteria from taptapani hot water spring, Orissa, India. Biotechnol Res Int 2011;2011:452710.

6. Gray KA, Zhao L, Emptage M. Bioethanol. Curr Opin Chem Biol 2006;10:141-6.

7. Wyman CE. Potential synergies and challenges in refining cellulosic biomass to fuels, chemicals, and power. Biotechnol Prog 2003;19:254-62.

8. Zaldivar J, Nielsen J, Olsson L. Fuel ethanol production from lignocellulose: A challenge for metabolic engineering and process integration. Appl Microbiol Biotechnol 2001;56:17-34.

9. Rabinovich ML. Ethanol production from materials containing cellulose: The potential of approaches developed in Russia. Prikl Biokhim Mikrobiol 2006;42:5-32.

10. Ranjit M, editor. Geothermal Energy Update of Nepal. Indonesia: Proceedings of the 2010 World Geothermal Congress; 2010.

11. Yadav RK, Timilsina A, Yadawa RK, Pokhrel CP. Potential cellulosic ethanol production from organic residues of agro-based industries in Nepal. ISRN Renew Energy 2014;2014:6.

12. Akmar HN, Asma I, Venugopal B, Latha LY, Sasidharan S. Identification of appropriate sample and culture method for isolation of new thermophilic bacteria from hot spring. Afr J Microbiol Res 2011;5:217-21.

13. Silva PD, Nahas E. Bacterial diversity in soil in response to different plans, phosphate fertilizers and liming. Braz J Microbiol 2002;33:304-10.

14. Mc Faddin JF. Pruebas Bioquimicas Para la Identificacion de Bacterias de Importancia Clinica. Buenos Aires: Panamericana; 1984. p. 11-301.

15. Abd-Elhalem BT, El-Sawy M, Gamal RF, Abou-Taleb KA. Production of amylases from Bacillus amyloliquefaciens under submerged fermentation using some agro-industrial by-products.
Ann Agric Sci 2015;60:193-202

16. Zhou MY, Chen XL, Zhao HL, Dang HY, Luan XW, Zhang XY, et al. Diversity of both the cultivable protease-producing bacteria and their extracellular proteases in the sediments of the South China sea. Microb Ecol 2009;58:582-90.

17. Kasana RC, Salwan R, Dhar H, Dutt S, Gulati A. A rapid and easy method for the detection of microbial cellulases on agar plates using gram's iodine. Curr Microbiol 2008;57:503-7.

18. Singh AK, Tripathi BM, Sahay H, Singh RN, Kaushik R, Saxena AK, et al. Biochemical and molecular characterization of thermo-alkali tolerant xylanase producing bacteria from thermal springs of Manikaran. Indian J Microbiol 2010;50:2-9.

19. Tanasupawat S, Phoottosavako M, Keeratipibul S. Characterization and lipolytic activity of lactic acid bacteria isolated from Thai fermented meat. J Appl Pharm Sci 2015;5:6-12.

20. Whaley DN, Dowell VR Jr. Wanderlinder LM, Lombard GL. Gelatin agar medium for detecting gelatinase production by anaerobic bacteria. J Clin Microbiol 1982;16:224-9.

21. Padilha I, Carvalho L, Dias P, Grisi T, Silva F, Santos S, et al. Production and characterization of thermophilic carboxymethyl cellulase synthesized by Bacillus sp. Growing on sugarcane bagasse in submerged fermentation. Braz J Chem Eng 2015;32:35-42.

22. Assareh R, Shahbani Zahiri H, Akbari Noghabi K, Aminzadeh S, Bakhshi Khaniki G. Characterization of the newly isolated Geobacillus sp. T1, the efficient cellulase-producer on untreated barley and wheat straws. Bioresour Technol 2012;120:99-105.

23. Yassien MA, Jiman-Fatani AA, Asfour HZ. Production, purification and characterization of cellulase from Streptomyces sp. Afr J Microbiol Res 2014;8:348-54.

24. Bhalla A, Bischoff KM, Sani RK. Highly thermostable xylanase production from A thermophilic Geobacillus sp. Strain WSUCF1 utilizing lignocellulosic biomass. Front Bioeng Biotechnol 2015;3:84.

25. Rasooli I, Astaneh SD, Borna H, Barchini KA. A thermostable $\alpha$-amylase producing natural variant of Bacillus spp. isolated from soil in Iran. Am J Agric Biol Sci 2008;3:591-6.

26. Lo YC, Saratale GD, Chen WM, Bai MD, Chang JS. Isolation of cellulose-hydrolytic bacteria and applications of the cellulolytic enzymes for cellulosic biohydrogen production. Enzyme Microb Technol 2009;44:417-25.

27. Bond PL, Smriga SP, Banfield JF. Phylogeny of microorganisms populating a thick, subaerial, predominantly lithotrophic biofilm at an extreme acid mine drainage site. Appl Environ Microbiol 2000;66:3842-9.

28. Singh PK, Kumari A, Chawla N, Pinnaka AK, Korpole S. Rhodococcus lactis sp. Nov. an actinobacterium isolated from sludge of a dairy waste treatment plant. Int J Syst Evol Microbiol 2015;65:4215-20.

29. Kim OS, Cho YJ, Lee K, Yoon SH, Kim M, Na H, et al. Introducing ezTaxon-e: A prokaryotic 16S rRNA gene sequence database with phylotypes that represent uncultured species. Int J Syst Evol Microbiol 2012;62:716-21.

30. Kamble RD, Jadhav AR. Isolation, purification, and characterization of xylanase produced by a new species of Bacillus in solid state fermentation. Int J Microbiol 2012;2012:683193.

31. Adhikari H, Ghimire S, Khatri B, Yuvraj KC. Enzymatic screening and molecular characterization of thermophilic bacterial strains isolated from hot spring of Tatopani, Bhurung, Nepal. Int J Appl Sci 2015;3:392-7.

32. Kristjansson JK. Thermophilic organisms as sources of thermostable enzymes. Trends Biotechnol 1989;7:349-53.

33. Liang Y, Feng Z, Yesuf J, Blackburn JW. Optimization of growth medium and enzyme assay conditions for crude cellulases produced by a novel thermophilic and cellulolytic bacterium, Anoxybacillus sp 
527. Appl Biochem Biotechnol 2010;160:1841-52.

34. Goh KM, Kahar UM, Chai YY, Chong CS, Chai KP, Ranjani V, et al. Recent discoveries and applications of Anoxybacillus. Appl Microbiol Biotechnol 2013;97:1475-88.

35. Lynd LR, Weimer PJ, van Zyl WH, Pretorius IS. Microbial cellulose utilization: Fundamentals and biotechnology. Microbiol Mol Biol Rev 2002;66:506-77.

36. Logan NA, Berkeley RC. Identification of Bacillus strains using the API system. J Gen Microbiol 1984;130:1871-82.

37. Yohandini H. Isolation and phylogenetic analysis of thermophile community within tanjung sakti hot spring, South Sumatera, Indonesia. HAYATI J Biosci 2015;22:143-8

38. Aditiawati P, Yohandini H, Madayanti F, Akhmaloka. Microbial diversity of acidic hot spring (kawah hujan B) in geothermal field of Kamojang area, West Java-Indonesia. Open Microbiol J 2009;3:58-66.

39. Cihan AC, Tekin N, Ozcan B, Cokmus C. The genetic diversity of genus Bacillus and the related genera revealed by 16s rRNA gene sequences and ardra analyses isolated from geothermal regions of Turkey. Braz J Microbiol 2012;43:309-24.

40. Baker GC, Gaffar S, Cowan DA, Suharto AR. Bacterial community analysis of Indonesian hot springs. FEMS Microbiol Lett 2001;200:103-9.

41. Turner P, Mamo G, Karlsson EN. Potential and utilization of thermophiles and thermostable enzymes in biorefining. Microb Cell Fact 2007;6:9.

42. Paës G, O'Donohue MJ. Engineering increased thermostability in the thermostable GH-11 xylanase from Thermobacillus xylanilyticus.
J Biotechnol 2006;125:338-50.

43. Yan $\mathrm{S}, \mathrm{Wu} \mathrm{G}$. Secretory pathway of cellulase: A mini-review. Biotechnol Biofuels 2013;6:177.

44. Kahar UM, Chan KG, Salleh MM, Hii SM, Goh KM. A high molecular-mass Anoxybacillus sp. SK3-4 amylopullulanase: Characterization and its relationship in carbohydrate utilization. Int J Mol Sci 2013;14:11302-18.

45. Tsuda T, Sasaki Y, Kawashima R. Physiological Aspects of Digestion and Metabolism in Ruminants, Proceedings of the $7^{\text {th }}$ International Symposium on Ruminant Physiology. California: Academic Press; 2012.

46. Rastogi G, Muppidi GL, Gurram RN, Adhikari A, Bischoff KM, Hughes SR, et al. Isolation and characterization of cellulosedegrading bacteria from the deep subsurface of the homestake gold mine, lead, south dakota, USA. J Ind Microbiol Biotechnol 2009;36:585-98.

47. Logan NA, Forsyth G, Lebbe L, Goris J, Heyndrickx M, Balcaen A, et al. Polyphasic identification of Bacillus and Brevibacillus strains from clinical, dairy and industrial specimens and proposal of Brevibacillus invocatus sp. Nov. Int J Syst Evol Microbiol 2002;52:953-66.

\section{How to cite this article:}

Yadav P, Korpole S, Prasad GS, Sahni G, Maharjan J, Sreerama L,

Bhattarai T. Morphological, enzymatic screening, and phylogenetic analysis of thermophilic bacilli isolated from five hot springs of Myagdi, Nepal. J App Biol Biotech. 2018;6(3):1-8. DOI: 10.7324/JABB.2018.60301 